INTERNATIONAL FOOD POLICY

RESEARCH INSTITUTE

sustainable solutions for ending hunger and poverty

IFPRI ${ }^{\circledR}$ A member of the CGIAR consortium

IFPRI Discussion Paper 01265

April 2013

\title{
The Policy Landscape of Agricultural Water Management in Pakistan
}

\author{
Noora-Lisa Aberman \\ Benjamin Wielgosz \\ Fatima Zaidi \\ Claudia Ringler \\ Agha Ali Akram \\ Andrew Bell \\ Maikel Issermann
}

Environment and Production Technology Division 


\section{INTERNATIONAL FOOD POLICY RESEARCH INSTITUTE}

The International Food Policy Research Institute (IFPRI) was established in 1975 to identify and analyze national and international strategies and policies for meeting the food needs of the developing world on a sustainable basis, with particular emphasis on low-income countries and on the poorer groups in those countries. IFPRI is a member of the CGIAR Consortium.

\section{PARTNERS AND CONTRIBUTORS}

IFPRI gratefully acknowledges the generous unrestricted funding from Australia, Canada, China, Denmark, Finland, France, Germany, India, Ireland, Italy, Japan, the Netherlands, Norway, the Philippines, South Africa, Sweden, Switzerland, the United Kingdom, the United States, and the World Bank.

\section{AUTHORS}

Noora-Lisa Aberman, International Food Policy Research Institute

Program Analyst, Poverty, Health and Nutrition Division

n.aberman@cgiar.org

\section{Benjamin Wielgosz, International Food Policy Research Institute}

Research Analyst, Environment and Production Technology Division

Fatima Zaidi, International Food Policy Research Institute

Senior Research Assistant, Environment and Production Technology Division

Claudia Ringler, International Food Policy Research Institute

Deputy Division Director and Senior Research Fellow, Environment and Production Technology Division

Agha Ali Akram, Yale University

$\mathrm{PhD}$ Candidate, School of Forestry and Environmental Studies

Andrew Bell, International Food Policy Research Institute

Research Fellow, Environment and Production Technology Division

Maikel Issermann, Tsinghua University, School of Environment

Master of Environmental Science \& Engineering Candidate

Notices

IFPRI Discussion Papers contain preliminary material and research results. They have been peer reviewed, but have not been subject to a formal external review via IFPRI's Publications Review Committee. They are circulated in order to stimulate discussion and critical comment; any opinions expressed are those of the author(s) and do not necessarily reflect the policies or opinions of IFPRI.

Copyright 2013 International Food Policy Research Institute. All rights reserved. Sections of this material may be reproduced for personal and not-for-profit use without the express written permission of but with acknowledgment to IFPRI. To reproduce the material contained herein for profit or commercial use requires express written permission. To obtain permission, contact the Communications Division at ifpri-copyright@cgiar.org. 


\section{Contents}

Abstract $\quad$ V

Acknowledgments $\quad$ vi

Abbreviations and Acronyms vii

1. Objectives 1

2. Interview Method 2

3. Analysis and Discussion Results 4

4. Conclusions 18

Appendix: Supplementary Tables 19

References $\quad 21$ 


\section{Tables}

3.1-Comparison of centrality and influence scores, national discussion 5

3.2-Centrality and influence comparison, provincial discussions 12

A.1-National map: Complete actor list 19

$\begin{array}{ll}\text { A.2-Punjab map: Complete actor list } & 20\end{array}$

\section{Figures}

3.1-Complete multiplex network, national discussion 4

3.2-Formal authority network, national discussion $\quad 6$

3.3-Informal pressure network, national discussions $\quad 7$

3.4-Technical information network, national discussions 8

3.5-Funding network, national discussions 9

3.6-Punjab complete multiplex network 11

3.7-Punjab formal authority network 13

3.8-Punjab technical information network 14

3.9-Punjab informal pressure network 15

3.10 - Punjab funding network $\quad 15$

\section{Boxes}

2.1-National Net-Map exercise 2

2.2-Punjab Net-Map exercise 2 


\begin{abstract}
Irrigation is central to Pakistan's agriculture; and managing the country's canal, ground, and surface water resources in a more efficient, equitable, and sustainable way will be crucial to meeting agricultural production challenges, including increasing agricultural productivity and adapting to climate change. The water component of the International Food Policy Research Institute's Pakistan Strategy Support Program (PSSP) is working to address these topics through high-quality research and policy engagement. As one of the first activities of this program, the PSSP undertook this assessment of the policy landscape for agricultural water management in Pakistan, to better understand how to engage with stakeholders in the landscape, and to assess possible opportunity points for improving water conservation.

The authors use the Net-Map method, an interview tool that combines stakeholder mapping, power mapping, and social network analysis, to examine the relationships between various institutions influencing the water sector in Pakistan. Group interviews were conducted with national stakeholders in Islamabad and with provincial stakeholders in Lahore to establish separate influence maps at the different scales. Interviewees were asked about four types of network relationships: formal authority, informal pressure, technical information, and funding. Network data was analyzed using social network analysis software and notes from interviews add further depth to the network observations. Concluding discussion focuses on the distribution of power and influence in the network and on the opportunities and challenges of recent governance reforms and implications for stakeholder engagement.
\end{abstract}

\title{
Keywords: Pakistan, water, agricultural water policy, Net-Map, social network analysis, stakeholder mapping, irrigation, governance
}




\section{ACKNOWLEDGMENTS}

The project team, consisting of Noora Aberman, Ben Wielgosz, and Fatima Zaidi of the International Food Policy Research Institute (IFPRI) and Ali Akram of Yale University, would like to express heartfelt thanks to the participants of the stakeholder workshops and others who contributed to pretesting activities. Their affiliations are listed below:

\section{National Interview}

- $\quad$ Federal Flood Commission

- $\quad$ Federal Water Management Cell

- Ministry of Science \& Technology

- Pakistan Agricultural Research Council

- Pakistan Council of Research in Water Resources, Ministry of Science \& Technology

- Pir Mehr Ali Shah University of Arid Agriculture

- Planning and Development Division, National Planning Commission

- Rural Support Program Network

- Water Resources, National Planning Commission

\section{Punjab Interview}

- Centre of Excellence in Water Resources Engineering

- Department of Irrigation \& Drainage, University of Agriculture, Faisalabad

- Development Policy Research Center, Lahore University of Management Sciences

- International Water Management Institute, Pakistan

- International Waterlogging and Salinity Research Institute

- Lahore University of Management Sciences

- Nuclear Institute for Agriculture and Biology

- On-Farm Water Management

- Water and Power Development Authority

- Water Management Research Center, University of Agriculture, Faisalabad

The team would also like to thank David Spielman and Eva Schiffer for their guidance on this activity. The excellent logistical support from staff at Innovative Development Strategies and the Lahore University of Management Sciences and from Betsy Pereira (IFPRI) is gratefully acknowledged as well. This work forms part of the Pakistan Strategy Support Program. 


\section{ABBREVIATIONS AND ACRONYMS}

FCAP

IPCC

IRSA

MoP\&D

MoWP

NPC

NRSP

PAD

PID

PIDA

PMO

PSSP

RSPN

RSPs

SDOs

SNA

UNICEF

USAID

WAPDA
Federation of Chamber of Agriculture, Pakistan

Inter-Provincial Coordination Committee

Indus River System Authority

Ministry of Planning \& Development

Ministry of Water and Power

National Planning Commission

National Rural Support Programme

Punjab Agriculture Department

Provincial Irrigation Department

Punjab Irrigation and Drainage Authority

prime minister's office

Pakistan Strategy Support Program

Rural Support Programme Network

Rural Support Programmes

sub-division officers

social network analysis

United Nations Children's Fund

United States Agency for International Development

Water and Power Development Authority 



\section{OBJECTIVES}

Irrigation is central to Pakistan's agriculture; and managing the country's canal, ground, and surface water resources in a more efficient, equitable, and sustainable way will be crucial to meeting agricultural production challenges, including increasing agricultural productivity and adapting to climate change. In spite of significant investments in raising irrigation efficiency, low agricultural water productivity is still one of the key issues challenging water use sustainability and food security in Pakistan. Groundwater provides more than 40 percent of water used for irrigation, particularly in Punjab, and is now being rapidly depleted due to inexpensive drilling technology, cheaper pump-sets, and greater control of water use by farmers.

Given increasing energy and food prices, growing water scarcity, and increased frequency and intensity of extreme events - possibly related to global climate change-Pakistan must start an open debate on how the interlinked objectives of water, energy, and food security can be jointly achieved, at minimal cost and maximum benefit for the Pakistani people.

The water component of the International Food Policy Research Institute's Pakistan Strategy Support Program (PSSP) is working to address these topics through high-quality research and policy engagement, working closely with the United States Agency for International Development (USAID) and the Pakistan government. As one of the first activities of this program, the PSSP undertook a stakeholder mapping activity to provide the project team with a basic understanding of the policy landscape for agricultural water management in Pakistan, to understand how to engage with stakeholders in the landscape, and to assess possible entry points for water conservation. The results reflect the perceptions of a group of key water management stakeholders about the informal interactions that drive water policy in Pakistan and also about how the formal interactions play out in practice. 


\section{INTERVIEW METHOD}

The primary method used for the stakeholder analysis was Net-Map. Net-Map (Schiffer and Waale 2008) is a participatory interview technique that combines social network analysis (Wasserman and Faust 1994), stakeholder mapping, and power mapping (Schiffer 2007). Net-Map helps people understand, visualize, discuss, and improve situations in which many different actors influence outcomes. By creating physical maps, individuals and groups can clarify their own view of a situation, foster discussion, and develop a strategic approach to their networking activities. The process can also help outsiders understand and monitor complex multi-stakeholder situations.

Net-Map allows stakeholders to examine not only the formal interactions in the network but also the informal interactions that cannot be understood by merely studying documents concerning formal policymaking procedures. Actors meet to exchange information and lobby for certain policy goals; local and international initiatives contribute by adding funds or research; and all of these interactions contribute to shaping the content and process of policymaking. To get a realistic understanding of these formal and informal links and how the actors use them to influence the policy process, empirical fieldwork is crucial (as only the formal links can be deducted from government documents). To understand how the actors interact with one another in the process, social network analysis (SNA) approaches are especially suitable, as they allow for a complex representation of a system, putting the actions of individuals and organizations into a greater perspective. SNA (Hanneman and Riddle 2005) explains the achievements of actors and the developments within groups of actors by looking at the structure of the linkages between these actors. Thus, while traditional survey-based approaches collect data about attributes of actors, network analysis focuses on gathering information about the network through which these actors connect. The Net-Map process typically involves the following three steps ${ }^{1}$ :

1. Actor generation: Who is involved in or tries to influence an issue?

2. Links: How do these actors interact? In what ways are they linked or related to the specific issue?

3. Influence: How influential is each of these actors in this issue?

Two Net-Map exercises were undertaken, one at the national level and one in Punjab. While the processes were the same in the two locations, the focus and scale were slightly different: The national interview focused on the influence over policy at the national level, and the Punjab interview discussed water policy influence in Punjab. Given Punjab's key role in agriculture in Pakistan, national-level decisions are particularly pertinent to and dependent on Punjab. Boxes 2.1 and 2.2 show the specifics of each exercise.

\section{Box 2.1-National Net-Map exercise}

Overall question: Who influences agricultural water management policy at the national level?

Links: Who has formal oversight over whom? Who provides funding to whom? Who provides technical advice to whom? Who pressures whom?

Influence: How influential is each actor over agricultural water management policy at the national level?

Source: Authors.

\footnotetext{
${ }^{1}$ A typical Net-Map usually includes a fourth step that examines the primary goals or priorities of each actor. This step was dropped in this exercise because of the challenges of pinpointing and the political sensitivity of specifying the competing goals.
} 


\section{Box 2.2-Punjab Net-Map exercise}

Overall question: Who influences agricultural water management policy in Punjab?

Links: Who has formal oversight over whom? Who provides funding to whom? Who provides technical advice to whom? Who pressures whom?

Influence: How influential is each actor over agricultural water management policy in Punjab?

Source: Authors.

The answers to these questions were arrived at by group consensus. The actors' names were written on small note cards and spread across a large piece of paper. Upon nominating an actor to be included, respondents explained why that actor was important to add. Next, links or flows were drawn between the actors, according to the group's knowledge and perceptions. The specific links drawn were formal oversight, depicting formal lines of authority, usually within the government; funding, depicting allocation of funds, grants, or loans; technical information, depicting provision of information related to technical aspects of agricultural water management; and pressure, depicting pushing for particular policy outcomes through informal mechanisms. Then influence scores were attributed to each actor's card as follows: scores in the Punjab exercise ranged from 0 (no influence) to 5 (highest degree of influence), and in the national exercise, 0 (no influence) to 3 (highest degree of influence).

The outputs from these exercises are (1) visual depictions of the network of perceived interactions related to agricultural water management in Pakistan from two perspectives, and (2) notes from the indepth discussions during the interview process. The network data were entered into a social network analysis program to better assess the network structure. The influence scores attributed by the respondents were inputted as well, so that the nodes (the representations of each stakeholder in the network) can be sized according to perceived influence over shaping agricultural water management policies and decisions. The visual depictions of the network and the key lessons learned from the networks, and in particular from the discussions with respondents, are described in the next section.

Some limitations of the data collection process should be noted. First, a small number of stakeholders were interviewed. Therefore, some divergent views may not be reflected here. Second, the participatory nature of the interviews combined with hierarchical culture and issues of status between participants may lead to some individuals having a louder voice in the results. In spite of these limitations, we feel confident that the exercises have produced an illustrative snapshot of the perceptions and ideas of stakeholders and that the process of facilitating consensus on each step of the interview process draws out the views of all involved.

In the rest this paper we provide an overview of the results from each exercise, and then the outcomes are compared and contrasted and the implications are discussed in the concluding section. 


\section{ANALYSIS AND DISCUSSION RESULTS}

\section{National Network Results}

The complete multiplex network combines information from four different types of flows that were captured in the national Net-Map interview. These links were formal authority, technical information, informal pressure, and funding. The resultant network includes 48 actors and 130 individual links. It has a very high level of centralization, meaning that a few actors are highly linked but most actors are not well connected. A core-periphery analysis shows that the Ministry of Finance, the Ministry of Planning \& Development (MoP\&D), and the provincial government make up the core of the network and all other actors are seen as the periphery (Figure 3.1).

Figure 3.1-Complete multiplex network, national discussion

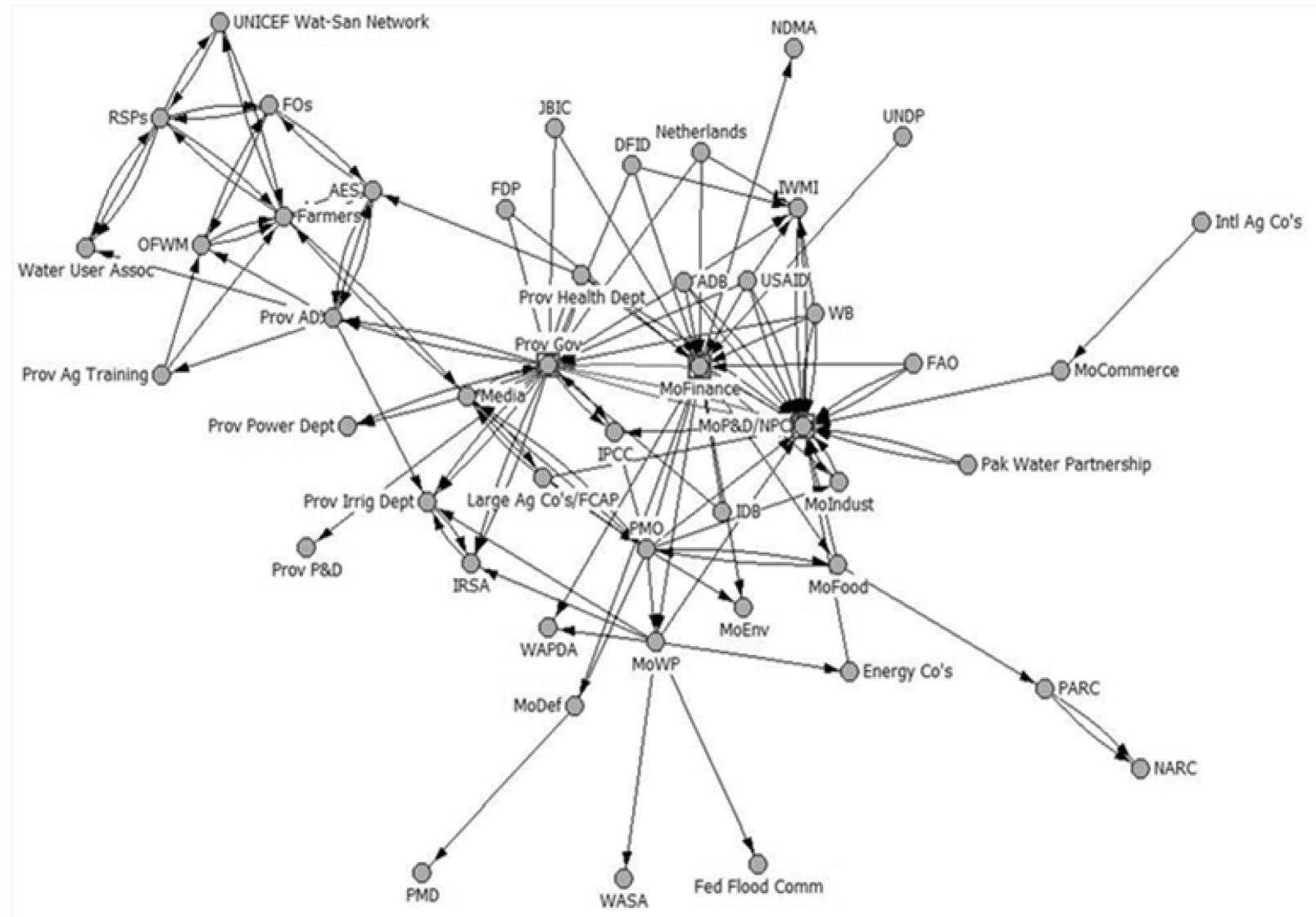

Source: Authors' calculations from Net-Map data, visualizations with VisuaLyzer software.

Notes: Multiplex network is made up of four types of links: formal authority, technical information, informal pressure, and funding. Core actors indicated with square around node.

See Table A.1 in the appendix for full names of actors.

Sixteen of the actors are a part of the federal government and nine are in the provincial government, making the majority of actors governmental. There is a combined total of 15 NGO's, UN, and donor organizations. Research plays a very small role in the network, with only three actors. 
Table 3.1 shows influence scores compared to degree of centrality, or the number of links that an actor has. "InDegree" refers to the number of arrows pointing to the particular actor, and "OutDegree" to the number of arrows pointing away from the actor. Those with the highest influence are largely governmental-Ministry of Finance, provincial government, MoP\&D/National Planning Commission (NPC), Provincial Irrigation Department, and Water and Power Development Authority (WAPDA) — with the exception of the media and the large-scale agricultural companies and their associations. The $\mathrm{MoP} \& \mathrm{D} / \mathrm{NPC}$ displays the starkest contrast, with 16 actors relating to this entity formally, informally, financially, or for technical information; while they have only one out-link with the Inter-Provincial Coordination Committee (IPCC).

Table 3.1-Comparison of centrality and influence scores, national discussion

\begin{tabular}{lrrrr}
\hline \multicolumn{1}{c}{ Actor } & Degree & InDegree & OutDegree & Influence \\
\hline Ministry of Finance & 20 & 11 & 9 & 3 \\
Provincial Government & 20 & 10 & 9 & 3 \\
Ministry of Planning and Development / National Planning & & & & \\
Commission & 17 & 16 & 1 & 3 \\
Prime Minister's Office & 12 & 4 & 8 & 2 \\
Ministry of Water and Power & 9 & 2 & 7 & 2 \\
Farmers & 9 & 6 & 3 & 0 \\
Rural Support Programs & 8 & 4 & 4 & 1 \\
Media & 8 & 4 & 4 & 3 \\
Provincial Agricultural Department & 7 & 2 & 5 & 2 \\
Large-Scale Agricultural Companies and Associations / & & & 3 & 3 \\
Federation of Chamber of Agriculture, Pakistan & 4 & 1 & 1 & 3 \\
Provincial Irrigation Department & 5 & 4 & 0 & 3 \\
Water and Power Development Authority & 2 & 2 & 1 & 2 \\
Inter-Provincial Coordination Committee & 3 & 2 & & 3 \\
\hline
\end{tabular}

Source: Authors' calculations from Net-Map data.

The actor with the highest influence is the provincial government. This actor also has the highest degree of centrality. The donors have the second highest influence but their degree of centrality is much lower than that of the provincial government, insinuating that the links they do have are highly influential. While the federal government does play a large role in the network, with the second highest degree of centrality, they are not seen as highly influential in provincial water management. This is particularly important as it reflects the changes in governance and power distribution that came with devolution-a process stemming from the passing of the Eighteenth Amendment of the Constitution, which mandated the decentralization of government power and began with the devolution of 18 federal ministries in 2011.

\section{Formal Authority}

The formal authority network (Figure 3.2) represents relationships of formal authority and oversight among actors. At the national level, the prime minister's office (PMO) has formal authority over the various ministries included in the map. At the provincial level, the provincial government has formal authority over the provincial departments. When interviewees referred to the provincial government, they considered it as representing the chief minister of the province, who is the lead decision-maker in the province and equivalent to the prime minister at the national level. 


\section{Figure 3.2-Formal authority network, national discussion}

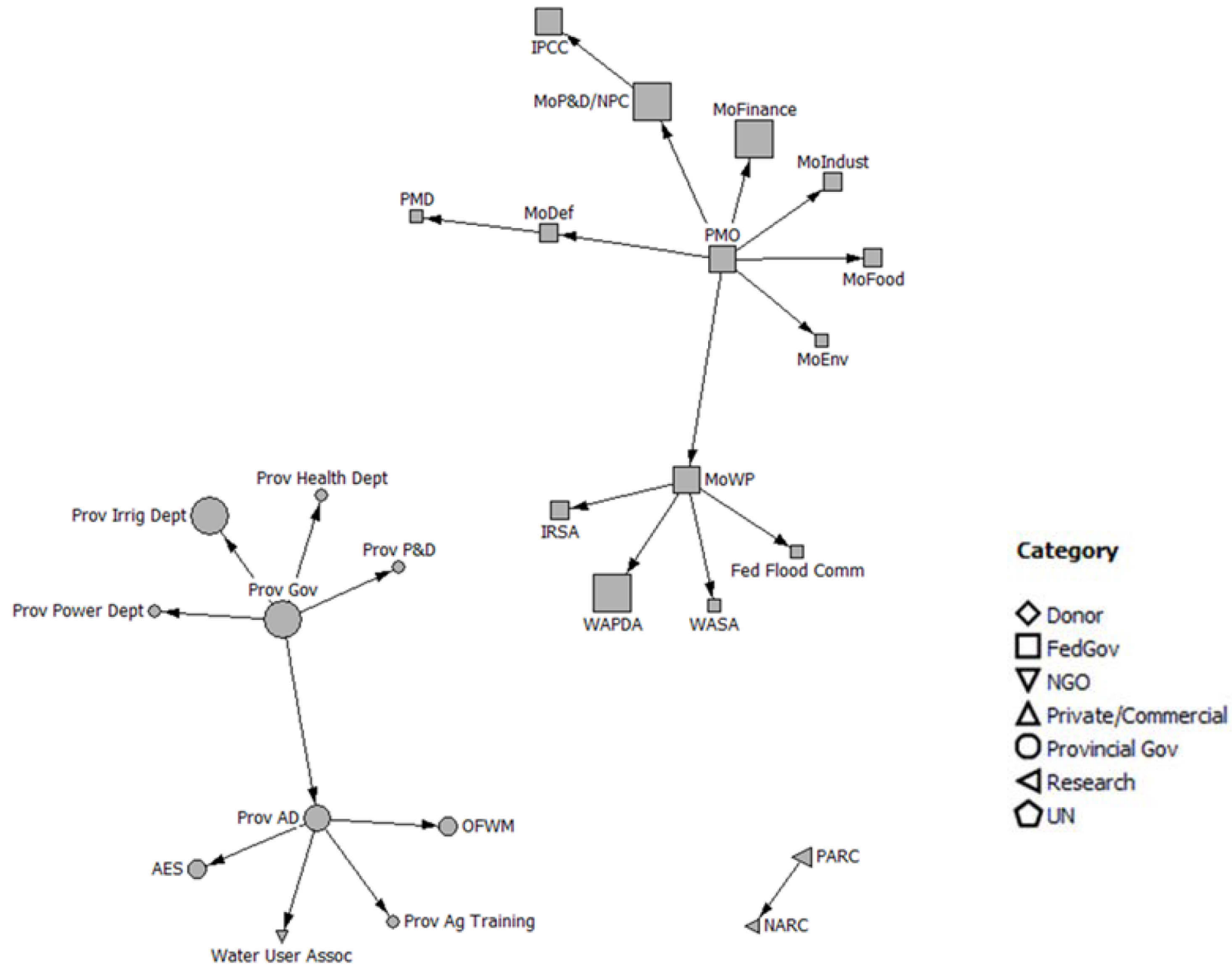

Source: Authors' calculations from Net-Map data, visualizations with VisuaLyzer software.

Notes: Actor category depicted by shape (see legend) and actor influence depicted by size.

See Table A.1 in the appendix for full list of actors.

\section{Informal Pressure}

The informal pressure network (Figure 3.3) represents flows of informal pressure related to agricultural water policy. In this network are 36 links total. The actors with the highest degree of centrality - highest number of pressure links - are the MoP\&D and the NPC. These actors were aggregated into a single actor because the NPC is under formal control of the MoP\&D; although the NPC is seen as an active decisionmaking body, it was also seen to always act in line with the views and preferences of the broader ministry. The types of actors pressuring MoP\&D/NPC include other government actors, NGO actors, private sector, and donors. All of its informal pressure links are incoming, meaning that it also has the highest in-degree centrality, which is the total count of incoming links. 
Figure 3.3-Informal pressure network, national discussions

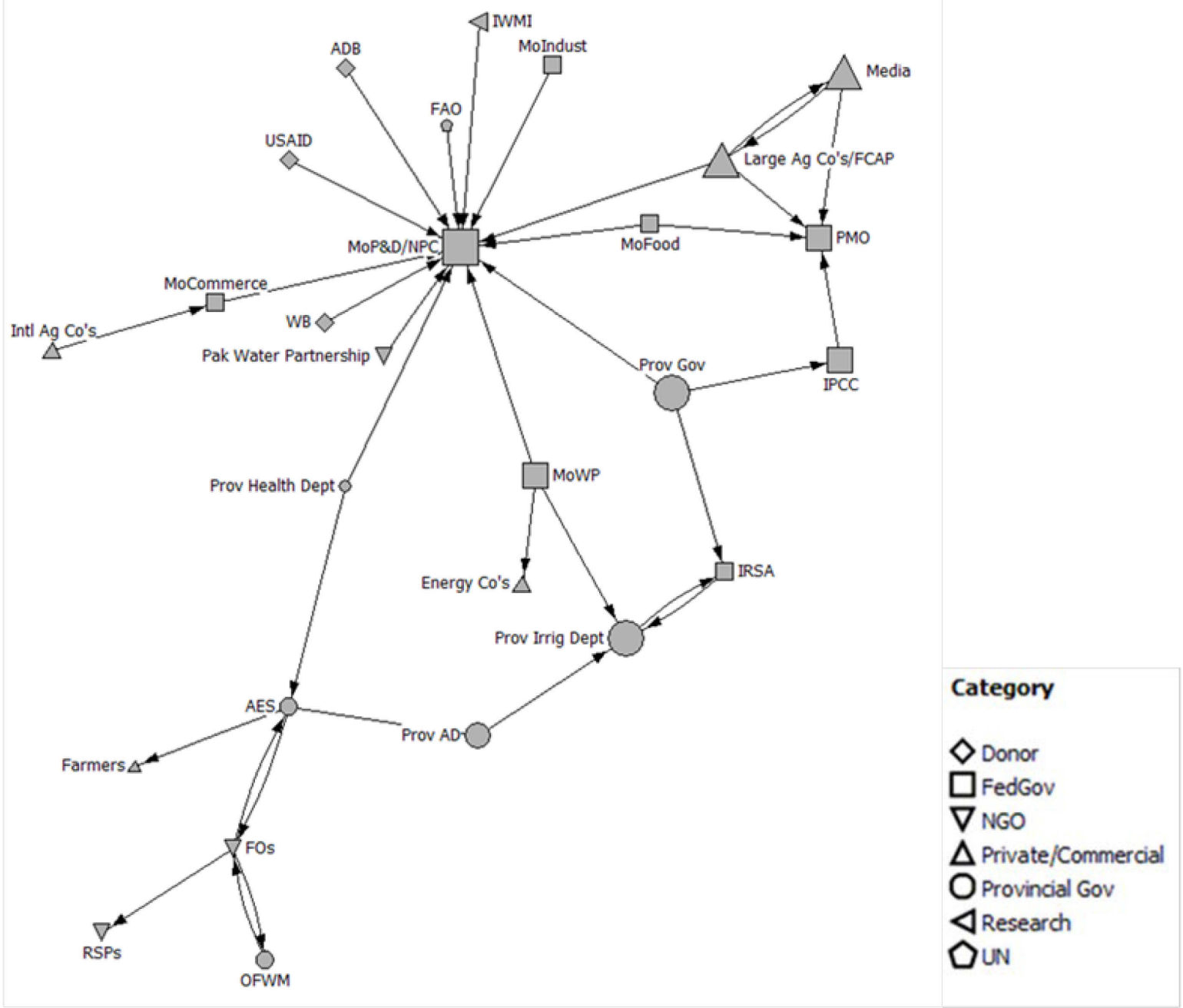

Source: Authors' calculations from Net-Map data, visualizations with VisuaLyzer software.

Notes: Actor category depicted by shape (see legend) and actor influence depicted by size. See Table A.1 in the appendix for full list of actors.

\section{Technical Information}

The technical information network (Figure 3.4) represents flows of technical information between actors related to agricultural water management. The actor with the most links (10) is the MoP\&D/NPC, which is only a recipient of technical information and thus has the highest degree of centrality and in-degree centrality. The MoP\&D/NPC can rely on diverse sources of information, including NGOs, research, UN, provincial government actors, national ministries, and private-sector companies. Farmers have nine links; they are primarily recipients of technical information but in some situations exchange information, such as with media, Rural Support Programmes (RSPs), and the United Nations Children's Fund (UNICEF) Water and Sanitation Network. The media and the RSPs have six links. The media exchange information with farmers and with influential government bodies. The RSPs exchange information with other local actors. The provincial government has five links and provides information to a few federal government actors and exchanges information with the media. 
Figure 3.4-Technical information network, national discussions

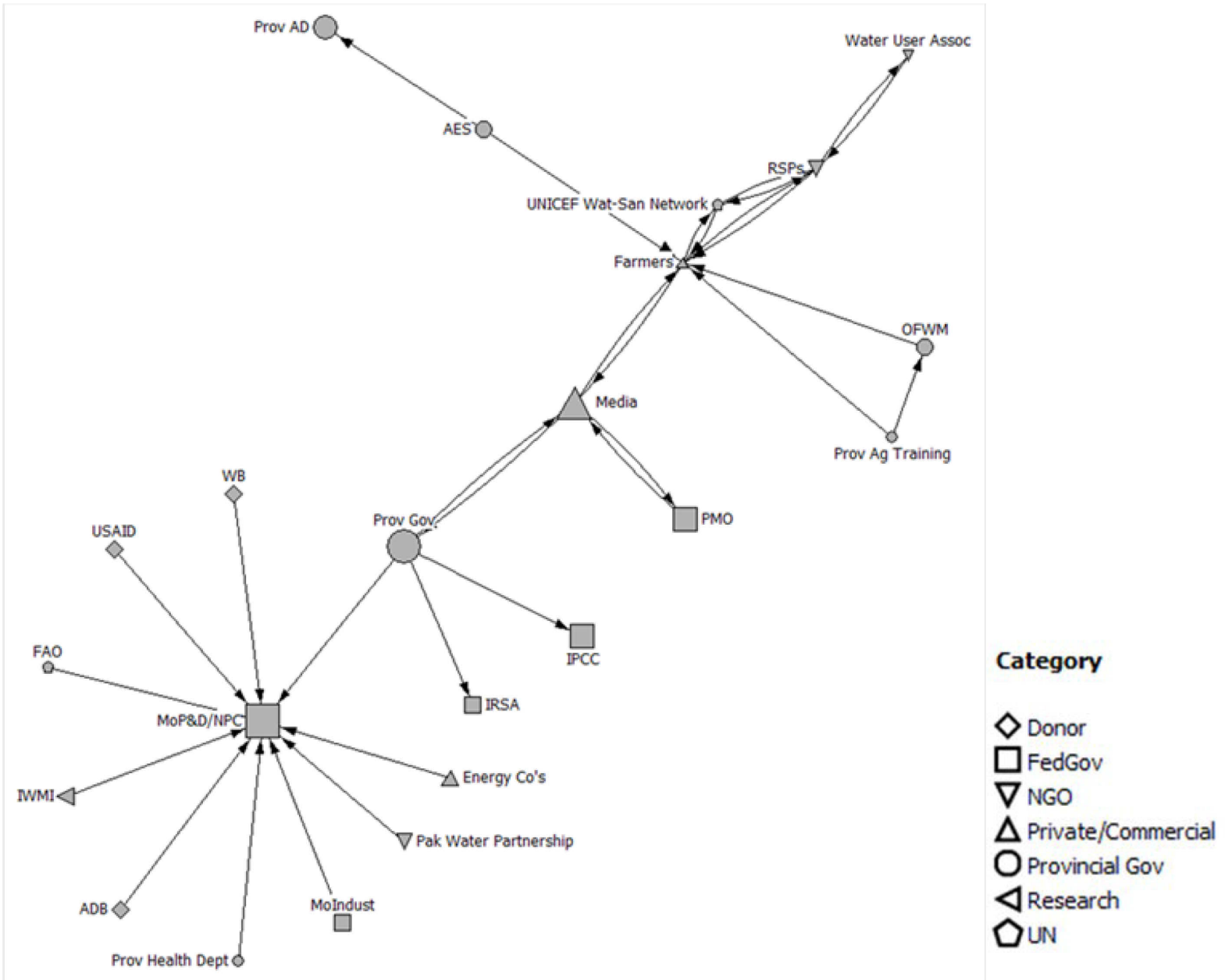

Source: Authors' calculations from Net-Map data, visualizations with VisuaLyzer software.

Notes: Actor category depicted by shape (see legend) and actor influence depicted by size.

See Table A.1 in the appendix for full list of actors.

\section{Funding}

The Funding flows in the network (figure 3.5) come primarily from external actors (donors and international organizations) to the Ministry of Finance, where they are allocated to other government bodies, including the provincial government. The role of the Ministry of Finance in allocating funds is the core rationale for its high influence level. In addition, some funds are provided directly to the provincial government from external actors, bypassing the national government. 
Figure 3.5-Funding network, national discussions

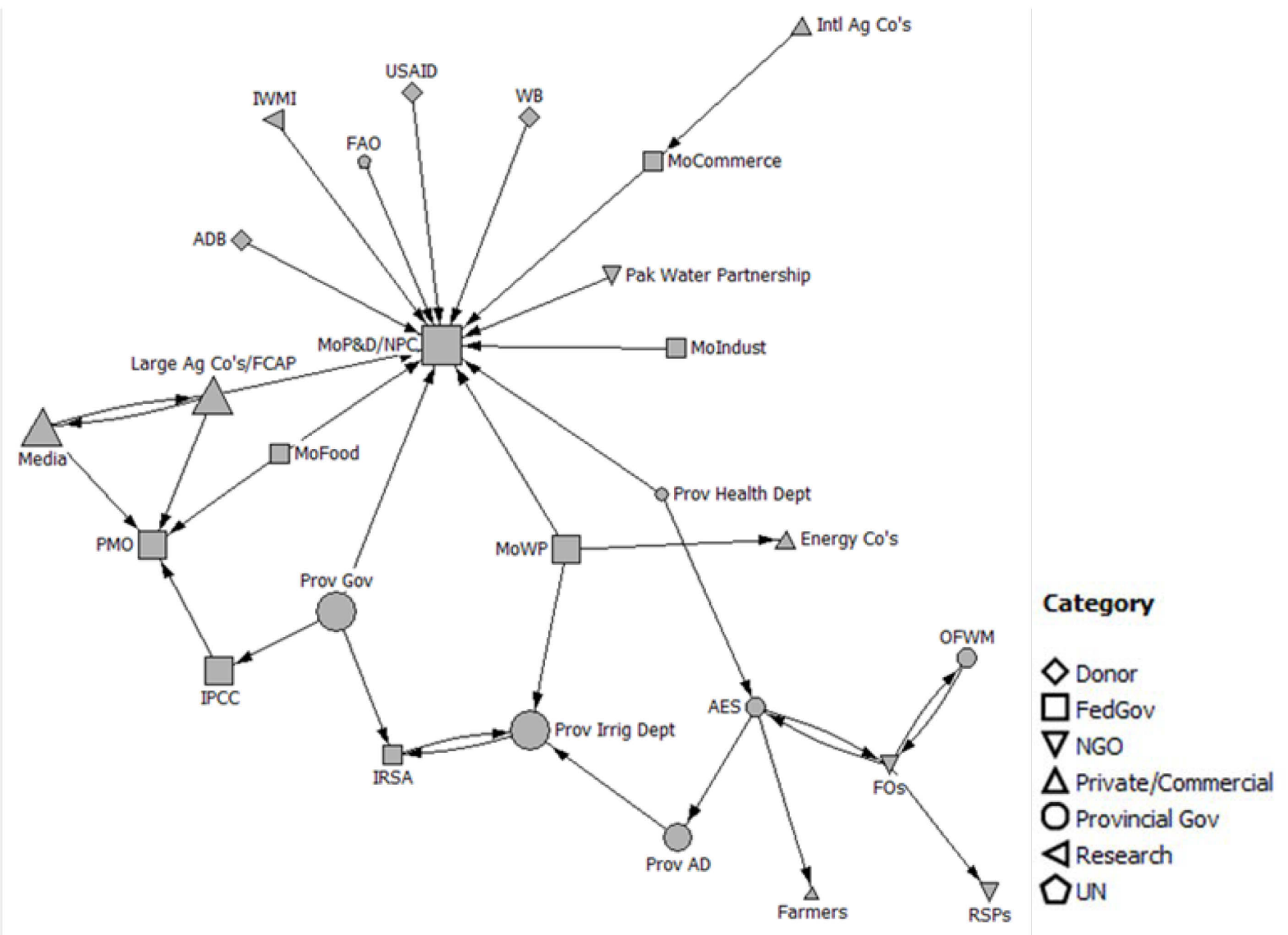

Source: Authors' calculations from Net-Map data, visualizations with VisuaLyzer software.

Notes: Actor category depicted by shape (see legend) and actor influence depicted by size.

See Table A.1 in the appendix for full list of actors.

\section{National Discussion Results}

\section{Federal Government Actors}

The federal government was central to discussions of water policy at the national level. Of the many federal government actors discussed, the MoP\&D — the elected government's main policymaking bodywas seen as the key government body in terms of water management. Within the MoP\&D, the NPC controls the allocation of budgetary resources, making it the primary focal point for those seeking to influence policy. The Ministry of Finance controls the disbursement of the NPC's budget allocations and has an interest in fiscal restraint. At times interview partners would refer to the MoP\&D, the NPC, and the PMO collectively as the federal government, viewing them as a cohesive decision-making body. To distinguish the distinct roles and positions of the various government actors, we maintained the PMO as a separate actor with distinct links. 
The Ministry of Water and Power (MoWP) is responsible for implementing many components of national water policies, particularly through its administrative responsibility for the Indus River System Authority (IRSA), WAPDA, and the Federal Flood Commission. IRSA is a major stakeholder in water distribution among the provinces because it is responsible for allocating Indus waters, the primary water source for Punjab and Sindh and therefore of particular significance to them. WAPDA is an important administrator and financier of the development of infrastructure for both irrigation and hydroelectric power generation. WAPDA is additionally responsible for addressing waterlogging and soil salinization, and it collaborates with provincial authorities on these matters through technical information sharing.

\section{Donors and Other Development Partners}

The World Bank was consistently described as the most influential donor at both the national and provincial levels due to its knowledge base and evidence in support of its policies prescriptions. This allows it more influence than its budget would indicate relative to other major donors. The World Bank provides funding for many policymaking activities and has been involved in the development of four successive national water policies since 2000. The World Bank has also become more invested in training and capacity-building activities, which are an essential complement to policy development.

The RSPs include the Rural Support Programme Network (RSPN) and the National Rural Support Programme (NRSP). RSPs are the key bodies working directly with farmers and communities to provide poverty alleviation programs including government-funded social welfare services. The RSPN has some influence over the NPC through the involvement of a few key individuals with great expertise such as Mr. Shoaib Sultan - who is the chair of the network - through his books and public presence.

\section{Private Sector}

The Federation of Chamber of Agriculture, Pakistan (FCAP), and other private industry associations ${ }^{2}$ were listed among those groups influencing national agricultural policies, including those relating to irrigation. Certain industries are very influential in agricultural policy through good representation in parliament. Political support for certain crop-related policies can indirectly favor water-intensive agricultural land use and increase incentives for over-extraction of available water resources.

\section{Punjab Network Results}

The complete multiplex network (Figure 3.6) combines information from four different types of flows that were captured in the Punjab Net-Map interview. These links are formal authority, technical information, informal pressure, and funding. The resultant network is much simpler than the national network, with 17 actors and 73 total links. It has very low centralization, which means that there is a relatively equal level of participation among all the actors.

\footnotetext{
${ }^{2}$ Pakistan Sugar Mills Association, Pakistan Cotton Ginners' Association, Rice Export Association of Pakistan, Wheat Traders Association of Pakistan, Pakistan Flour Mills Association, Pakistan Tobacco Board, and others.
} 


\section{Figure 3.6-Punjab complete multiplex network}

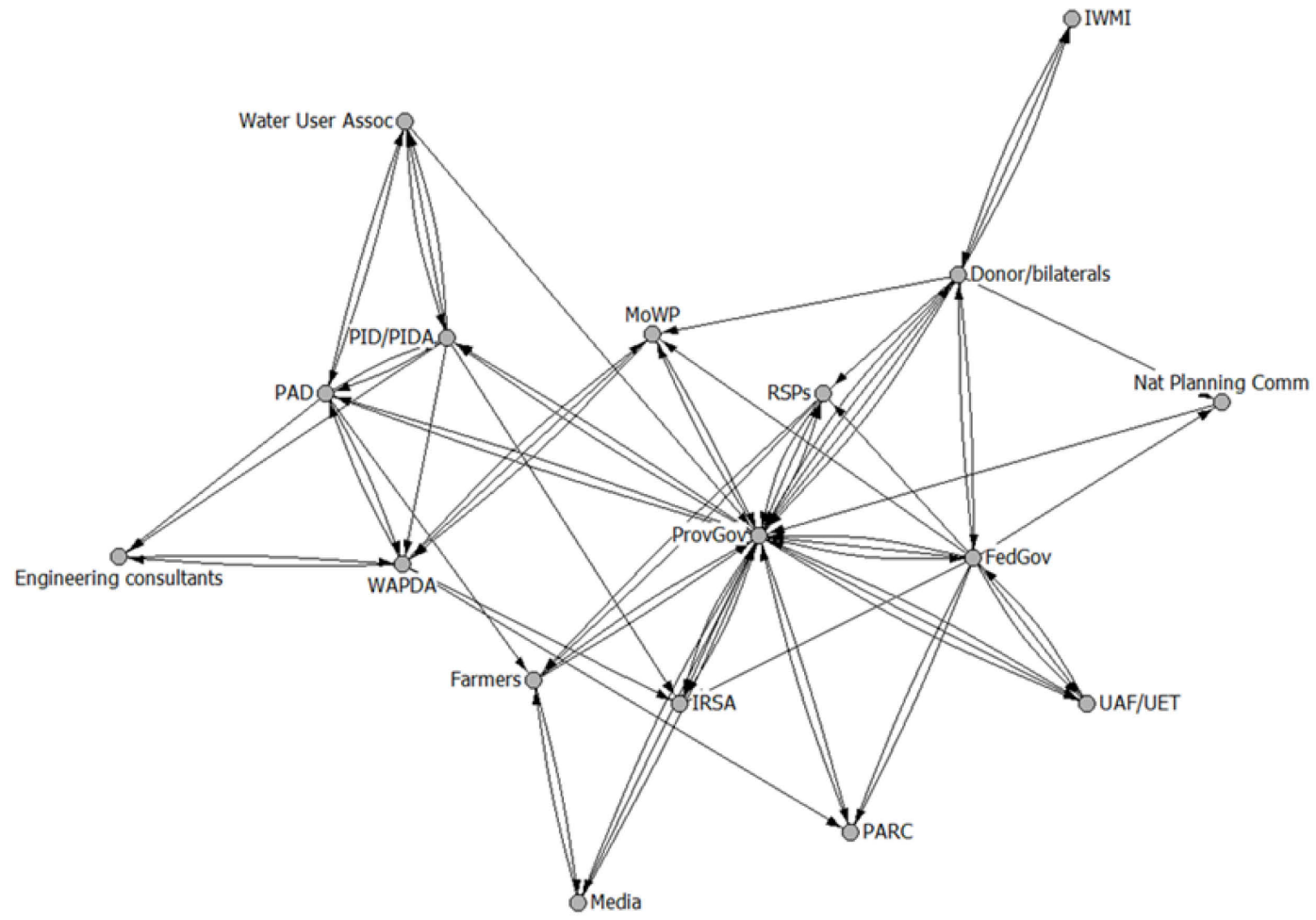

Source: Authors' calculations from Net-Map data, visualizations with VisuaLyzer software.

Notes: Multiplex network is made up of four types of links: formal authority, technical information, informal pressure, and funding.

See Table A.1 in the appendix for full list of actors.

Although the network depicts agricultural water management within Punjab, the federal government still plays a large role, with five national government actors and only four provincial government actors. Research plays a somewhat larger role here than at the national level, with three actors in this category.

Similar to Table 3.1, Table 3.2 presents influence scores compared to centrality values or the number of links (total, incoming and outgoing) that an actor has. The provincial government shows both highest influence and the largest number of links with other actors, while donors rank second with just half the links. 
Table 3.2-Centrality and influence comparison, provincial discussions

\begin{tabular}{lrrrr}
\hline Actor & Degree & InDegree & OutDegree & Influence \\
\hline Punjab Government & 21 & 11 & 10 & 5 \\
Federal Government/Prime Minister's & 11 & 3 & 8 & 2 \\
Office & & & & \\
Punjab Agriculture Department / & 9 & 4 & 5 & 2 \\
OFWM & 9 & 3 & 6 & 4 \\
Donor/bilaterals & 9 & 4 & 5 & 3 \\
Water and Power Development & & & & \\
Authority & 8 & 3 & 5 & 3 \\
Provincial Irrigation Department Punjab & 6 & 4 & 2 & 3 \\
Irrigation and Drainage & 5 & 4 & 1 & 1 \\
Ministry for Water and Power & 5 & 2 & 3 & 1 \\
Indus River System Authority & 5 & 3 & 2 & 2 \\
Water Users Associations, Farmer & 4 & 3 & 1 & 0 \\
Organizations, Farmer Boards & 4 & 2 & 2 & 1 \\
Farmers & 4 & 3 & 1 & 0 \\
Engineering consultants & 4 & 2 & 2 & 0 \\
Media & 3 & 2 & 1 & 0 \\
Pakistan Agriculture Research Council & 2 & 1 & 1 & 0 \\
Universities & & &
\end{tabular}

Source: Authors' calculations from Net-Map data.

Notes: Included in donors and bilaterals are the following organizations: JICA, WB, ADB, JBIC, Dutch Government, USAID; Included in engineering consultants, are the following companies: NESPAK National Engineering Services Pakistan; Associated Consulting Engineers ACE Pvt. Ltd.; Included in universities (abbreviated as UAF/UET ): University of Agriculture of Faisalabad, University of Engineering \& Technology Center for Excellence in Research.

\section{Formal Authority Network}

The formal authority network of actors influential in Punjab's water management is quite simple (Figure 3.7). At the provincial level are only three actors seen as having formal authority links, with the provincial government at the top. Federal-level actors are also seen as playing a role in Punjab's water management, with the federal government at the top. 
Figure 3.7-Punjab formal authority network

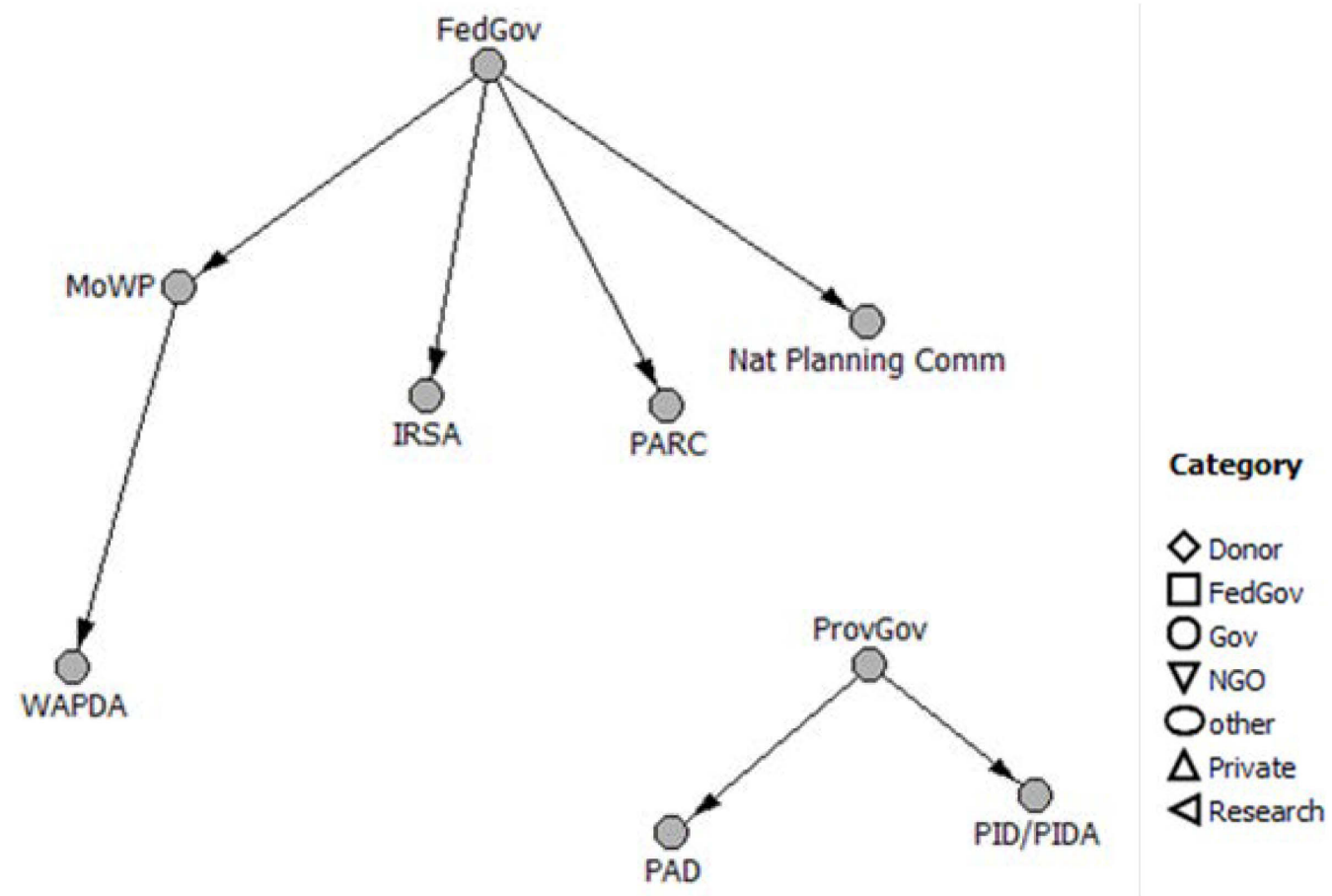

Source: Authors' calculations from Net-Map data, visualizations with VisuaLyzer software.

Note: See Table A.1 in the appendix for the full list of actors.

\section{Technical Information Network}

Most flows of technical information in the network are two-directional, which means they reflect exchanges of information (Figure 3.8). The actor with the highest degree of centrality (the highest number of links) is the provincial government, with 16 links ( 8 incoming and 8 outgoing). The provincial government exchanges information on water management with many different types of actors, including the federal government, research, media, NGOs, and donors and bi-laterals.

The Punjab Agriculture Department (PAD) has the second highest centrality, with seven total links. PAD is one of few (three) actors that gives information to farmers. In addition, PAD is linked directly to the federal government body WAPDA. 
Figure 3.8-Punjab technical information network

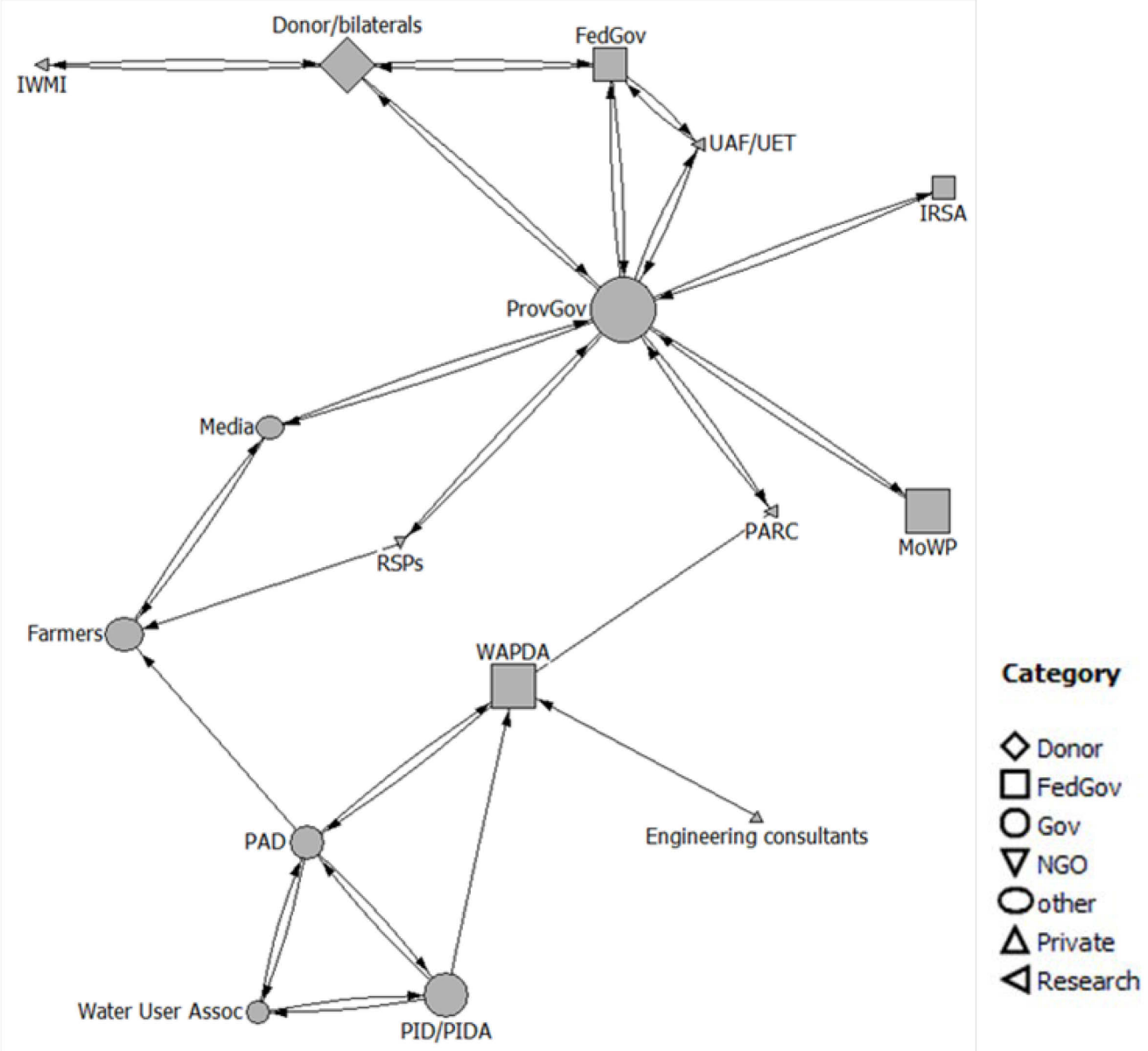

Source: Authors' calculations from Net-Map data, visualizations with VisuaLyzer software.

Note: See Table A.1 in the appendix for the full list of actors.

\section{Informal Pressure Network}

Once again the provincial government is the most central actor in the network in terms of degree centrality with five of the network's six total links (Figure 3.9). The provincial government receives pressure from farmers, which is noteworthy because it is not connected to farmers by any of the other links, with the exception of a funding link to pay for water use. The provincial government pressures only one actor: IRSA. In a separate component of the network, PID/PIDA (the Provincial Irrigation Department and the Punjab Irrigation and Drainage Authority) pressures one actor, the Water User Associations. 
Figure 3.9-Punjab informal pressure network

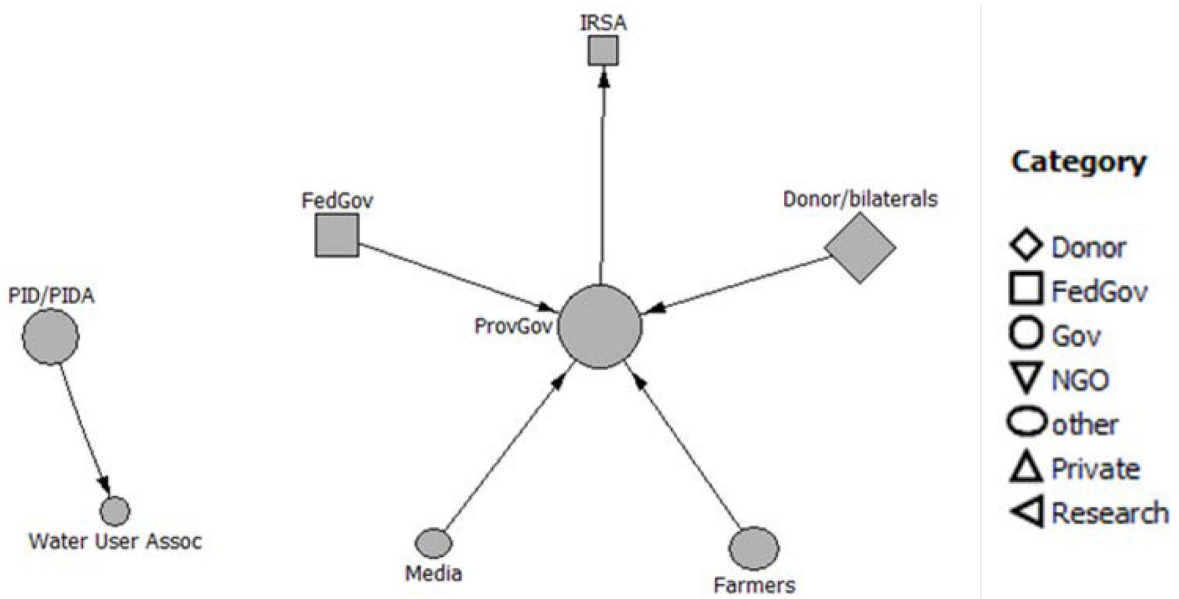

Source: Authors' calculations from Net-Map data, visualizations with VisuaLyzer software.

Note: See Table A.1 in the appendix for the full list of actors.

\section{Funding Network}

The provincial government has an equal number of incoming funding links as outgoing (Figure 3.10). This indicates that it may play the role of a conduit for funding, receiving from some (NPC and donors) and then allocating these down to others (PAD and PID/PIDA). The RSPs - the key mechanisms for support for farmers - are seen as NGOs but receive both external funds from donors and bi-laterals and governmental funds from the provincial and federal governments.

\section{Figure 3.10—Punjab funding network}

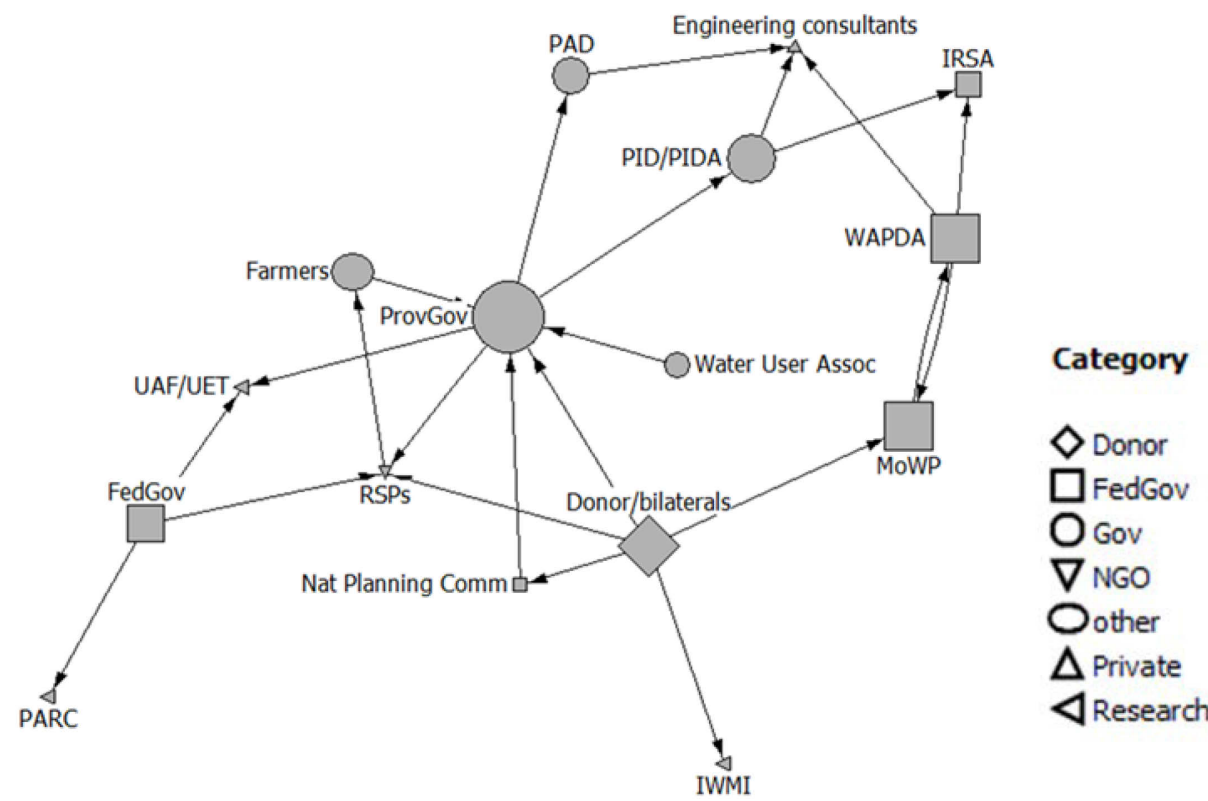

Source: Authors' calculations from Net-Map data, visualizations with VisuaLyzer software.

Note: See Table A.1 in the appendix for the full list of actors. 
Farmers receive funds from RSPs in the form of small loans and other financial and in-kind support. They are also obligated to pay the provincial government for their water use. Private-sector engineering consultants receive funding from both provincial government bodies-PAD and

PID/PIDA - and the federal government body WAPDA to undertake various engineering projects at the provincial level.

\section{Punjab Discussion Results}

Interviewees in the Punjab Net-Map session discussed the network of actors on agricultural water management in the province, the roles they play, and their ability to influence relevant policy and programs. Below we summarize the main points that came out of that discussion, reflecting the opinions and perspectives of the interviewees.

\section{Provincial Government}

The provincial government played a prominent role in the Punjab Net-Map discussions. When interviewees discussed the provincial government, they were typically referring to the highest government authority at the province level, the chief minister's office. However, at times they would also discuss the provincial government as the provincial politicians and legislators. In the provinces, the chief secretary plays a coordinating role among different ministries and is their channel of communication to the chief minister. The chief minister's office also liaises at the federal level to influence federal policy.

The central policymaking and decision-making body is the Planning and Development Department (the provincial-level office of the Ministry of Planning and Development). It allocates and coordinates flows of resources from the federal government to the province. It works with the Finance Department, which disburses the funds.

PID was described as "the powerful owner of water in Punjab." The engineers and sub-division officers (SDOs) who are part of the department are seen as the local decision-makers within PID. Interestingly, water dispute settlement powers also reside with the PID, which means that civil engineers might be acting as magistrates on such disputes.

In an attempt to increase the role of water users (farmers) in the decision-making processes, the World Bank spearheaded a water management reform initiative. This led to the creation of PIDA, which gives more power to water users through Water User Associations and other mechanisms. In Punjab, the PIDA reform process has not been enforced in its entirety yet. ${ }^{3}$ The intention of the reform was to have PIDA autonomously govern canal allocations, but they are currently still governed by PID. Interviewees explained that there is tension between PIDA and PID regarding which body should rightfully have authority over water management. They also stated that the transition to a PIDA-governed participatory system has likely not taken place due to the vested interests of those in power.

Another interesting point raised by interviewees related to the PIDA system was the elite capture of the participatory organizations by owners of large, wealthy farms. These land-owning farmers are seen as usurping the participatory organizations to further their own interests rather than the interests of tenantfarmers or hired farm-laborers. Furthermore, land-owning farmers were also seen as pressuring the government (denoted in the pressure network above) to provide preferential treatment, including through the provision of subsidies and infrastructure support in the form of consistent water flow, lining of canals, and higher quality of extension services.

\footnotetext{
${ }^{3}$ Interviewees noted that the reform process is further ahead in the other agriculture-heavy province of Sindh, where the Sindh Irrigation and Drainage Authority functions autonomously
} 


\section{Donors and Other Development Partners}

Since the devolution, donors have been providing funds directly to the provincial government. Thus, these funds, often coming in the form of low-interest loans, are a provincial liability, but in most cases the provincial Planning and Development Department requires approval and underwriting of the federal government.

As with the national interviewees, Punjab interviewees considered the World Bank to be the most powerful and influential donor in Punjab. Although the World Bank provides only a relatively small portion of the province's total budget, it is seen as having a tremendous amount of influence due to the strength of the evidence and knowledge that it brings to the policy dialogue.

In the Punjab network, the actor RSP includes the RSPN and the NRSP - in as far as they operate in the province - as well as the Punjab Rural Support Programme (PRSP). RSPs work directly with the farmers and communities to provide government-funded social welfare services, microcredit loans, and other poverty alleviation programs. They are not governmental bodies but do work closely with and receive funds from the government. Regarding water, RSPs in Punjab are working on soil reclamation, community cooperatives, and microcredit for tube wells and machinery. Other projects include technology dissemination such as tube wells and drip/lift irrigation, and more generally, education about water conservation practices in arid regions. 


\section{CONCLUSIONS}

The results of the two Net-Map exercises described above illustrate two distinct yet overlapping networks. Network structures and specific actors are different across the two networks, but perceptions of the influence and roles of the key actors were largely consistent. This section reviews the key contrasting and supporting points across the two sets of discussions and then outlines some implications drawn from these results.

The national network was complex and highly centralized, with 48 actors and a strong coreperiphery structure. In contrast, the Punjab network was made up of far fewer actors (17) and had a very low level of centralization, indicating a relatively equal level of participation of all actors in the network, rather than a centrally dominated network as in the national map. One interesting aspect of the Punjab network in this regard is that, distinct from the national map, technical information is seen as almost entirely bi-directional; all those who receive technical information from another actor also provide it. This is not the case in the national map, where most national actors are directing technical information to the Ministry of Planning and Development (MoP\&D) and the National Planning Commission (NPC); and therefore the Punjab map depicts a certain equality of information flow rather than the typical model of pushing information to a single decision-making body.

In the Punjab map the federal government has high centrality but a relatively low influence score. Furthermore, at the national level, the provincial government is seen as an active player in national policy, providing pressure and information to the key national government bodies (MoP\&D and NPC). This likely reflects both the recent decentralization of power to the provinces and the fact that Punjab is the key province for agricultural water management issues.

The funding network in the national Net-Map shows how the provinces are now directly targeted with funds, as a result of the devolution process. External funders largely focus equally on the provincial government and the federal government. Although the national map shows many sources of external funding, the World Bank was considered the key donor both nationally and in Punjab. There was some discussion in the Punjab interview of push-back on certain World Bank directives, indicating some divergence of priorities and some provincial autonomy in spite of this donor's highly influential position.

Some implications for water management policy and research follow. Firstly, there is a need for investment in capacity building and management training for agricultural water management. It was noted that the "best and brightest" do not enter this sector due to a lack of a clear career path in this sector and the fact that the sector is controlled by political appointees.

Also, competition among stakeholders for authority, resources, and influence over policy at times undermines the pursuit of common goals, which may become secondary to individual institutions' interests. While this is a common occurrence in policy and power negotiation, the incomplete reform of the Provincial Irrigation Department (PID) is a key casualty of such tussles. The current system is essentially made up of two redundant governing structures. It is possible that earlier involvement of PID representatives and leaders - focusing on maximizing collaboration and building consensus before defining and implementing changes - would have improved reform outcomes in the Punjab Irrigation and Drainage Authority (PIDA) reform process. Examining the more successful example of reforms in Sindh Province could provide additional concrete suggestions on how to move forward with the reform process.

Regarding the interview structure and method, the Net-Map exercise was selected to assess the roles and influence of institutions within the water policy system in Pakistan. Net-Map has proved useful for illuminating common perceptions of the institutional environment of water management policy, eliciting views on the obstacles to a successful policy reform process, and identifying the most influential and central stakeholders.

During the course of the interviews it became apparent that board governance and board appointments to important organizations would be an additional indicator of political and economic linkages between stakeholders to better understand the informal and influential networks at play. This is an important topic to consider for future institutional research in Pakistan. 


\section{APPENDIX: SUPPLEMENTARY TABLES}

Table A.1-National map: Complete actor list

\begin{tabular}{|c|c|}
\hline ADB & Asian Development Bank \\
\hline AES & Agricultural Extension Services \\
\hline DFID & Department for International Development \\
\hline Energy Co.'s & Energy companies \\
\hline FAO & Food and Agriculture Organization of the United Nations \\
\hline FDP & Friends of Democratic Pakistan \\
\hline Fed Flood Comm & Federal Flood Commission \\
\hline FOs & Farmer Organizations \\
\hline IDB & Islamic Development Bank \\
\hline Intl Ag Co.'s & International Agricultural Companies/Importers \\
\hline IPCC & Inter-Provincial Coordination Committee \\
\hline IRSA & Indus River System Authority \\
\hline IUCN & International Union for Conservation of Nature \\
\hline IWMI & International Water Management Institute \\
\hline JBIC & Japan Bank for International Cooperation \\
\hline Large Ag Co.'s/FCAP & $\begin{array}{l}\text { Large-Scale Agricultural Companies and Associations / Federation of Chamber of } \\
\text { Agriculture, Pakistan }\end{array}$ \\
\hline MoCommerce & Ministry of Commerce \\
\hline MoDef & Ministry of Defense \\
\hline MoEnv & Ministry of Environment \\
\hline MoFinance & Ministry of Finance \\
\hline MoFood & Ministry of Food Security and Research \\
\hline Molndust & Ministry of Industries \\
\hline MoP\&D/NPC & Ministry of Planning and Development / National Planning Commission \\
\hline MoWP & Ministry of Water and Power \\
\hline NARC & National Agricultural Research Centre \\
\hline NDMA & National Disaster Management Authority \\
\hline OFWM & On-Farm Water Management \\
\hline Pak Water Partnership & Pakistan Water Partnership \\
\hline PARC & Pakistan Agricultural Research Council \\
\hline PCRWR & Pakistan Council of Research in Water Resources \\
\hline PMD & Pakistan Meteorological Department \\
\hline PMO & Prime Minister's Office \\
\hline Prov AD & Provincial Agricultural Department \\
\hline Prov Ag Training & Provincial Agricultural Training Institutes \\
\hline Prov Gov. & Provincial Government \\
\hline Prov Health Dept. & Provincial Health Department \\
\hline Prov Irrig. Dept. & Provincial Irrigation Department \\
\hline
\end{tabular}


Table A.1-Continued

\begin{tabular}{ll}
\hline $\begin{array}{l}\text { Prov P\&D } \\
\text { Prov Power Dept. }\end{array}$ & $\begin{array}{l}\text { Provincial Planning and Development Board } \\
\text { RSPs }\end{array}$ \\
& $\begin{array}{l}\text { Rural Support Programs including the Azad Jammu Kashmir Rural Support Programme } \\
\text { (AJKRSP), the Baluchistan Rural Support Programme (BRSP), the National Rural } \\
\text { Support Programme (NRSP), the Punjab Rural Support Programme (PRSP), and the } \\
\text { Sindh Rural Support Programme (SRSP) }\end{array}$ \\
UNDP & United Nations Development Programme \\
UNICEF Wat San & United Nations Children's Fund Water Sanitation Network \\
Network & United States Agency for International Development \\
USAID & Water and Power Development Authority \\
WAPDA & Water and Sanitation Agency \\
WASA & Water Users Associations \\
Water User Assoc & World Bank \\
WB &
\end{tabular}

Source: Authors' compilation.

Table A.2-Punjab map: Complete actor list

\begin{tabular}{|c|c|}
\hline ADB & Asian Development Bank (ADB), \\
\hline Donor/Bilaterals & JICA, WB, ADB, JBIC, Dutch Government, USAID (Donor/Bilaterals), \\
\hline engineering consultants & $\begin{array}{l}\text { NESPAK National Engineering Services Pakistan; Associated Consulting Engineers } \\
\text { ACE Pvt. Ltd; (engineering consultants), }\end{array}$ \\
\hline Fed Gov. & Federal Government, Prime Minister's Office (Fed Gov.), \\
\hline IRSA & Indus River System Authority (IRSA), \\
\hline IWMI & International Water Management Institute (IWMI), \\
\hline JBIC & Japan Bank for International Cooperation (JBIC), \\
\hline JICA & The Japan International Cooperation Agency (JICA), \\
\hline MoWP & Ministry for Water and Power (MoWP), \\
\hline Nat Planning Comm & National Planning Commission (Nat Planning Comm) \\
\hline PAD & Punjab Agriculture Department / OFWM (PAD), \\
\hline PARC & Pakistan Agriculture Research Council (PARC), \\
\hline PID/PIDA & $\begin{array}{l}\text { Provincial Irrigation Department / Punjab Irrigation and Drainage Authority } \\
\text { (PID/PIDA), }\end{array}$ \\
\hline ProvGov & Punjab Government (ProvGov), \\
\hline PRSP/NRSP & Punjab Rural Support Program / National Rural Support Program (PRSP/NRSP), \\
\hline UAF/UET & $\begin{array}{l}\text { University of Agriculture of Faisalabad, University of Engineering \& Technology } \\
\text { Center for Excellence in Research (UAF/UET), }\end{array}$ \\
\hline USAID & United States Agency for International Development (USAID), \\
\hline WAPDA & Water and Power Development Authority (WAPDA), \\
\hline Water User Assoc & $\begin{array}{l}\text { Water Users Associations, Farmer Organizations, Farmer Boards (Water User } \\
\text { Assoc), }\end{array}$ \\
\hline WB & World Bank (WB) \\
\hline
\end{tabular}

Source: Authors' compilation. 


\section{REFERENCES}

Hanneman, R. A., and M. Riddle. 2005. Introduction to Social Network Methods. Riverside, CA, US: University of California, Riverside. http://faculty.ucr.edu/ hanneman/.

Schiffer, E. 2007. "The Power Mapping Tool: A Method for the Empirical Research of Power Relations". Discussion Paper 703. Washington, DC: International Food Policy Research Institute.

Schiffer, E., and D. Waale. 2008. "Tracing Power and Influence in Networks: Net-Map as a Tool for Research and Strategic Network Planning.” Discussion Paper 772. Washington, DC: International Food Policy Research Institute.

Wasserman, S., and K. Faust. 1994. Social Network Analysis: Methods and Applications. Cambridge, UK: University Press. 



\section{RECENT IFPRI DISCUSSION PAPERS}

\section{For earlier discussion papers, please go to www.ifpri.org/pubs/pubs.htm\#dp. All discussion papers can be downloaded free of charge.}

1264. Who talks to whom in African agricultural research information networks?: The Malawi case. Klaus Droppelmann, Mariam A. T. J. Mapila, John Mazunda, Paul Thangata, and Jason Yauney, 2013.

1263. Measuring food policy research capacity: Indicators and typologies. Suresh Chandra Babu and Paul Dorosh, 2013.

1262. Does freer trade really lead to productivity growth?: Evidence from Africa. Lauren Bresnahan, Ian Coxhead, Jeremy Foltz, and Tewodaj Mogues, 2013.

1261. Data needs for gender analysis in agriculture. Cheryl Doss, 2013.

1260. Spillover effects of targeted subsidies: An assessment of fertilizer and improved seed use in Nigeria. Lenis Saweda Liverpool-Tasie and Sheu Salau, 2013

1259. The impact of irrigation on nutrition, health, and gender: A review paper with insights for Africa south of the Sahara. Laia Domenech and Claudia Ringler, 2013.

1258. Assessing the effectiveness of multistakeholder platforms: Agricultural and rural management councils in the Democratic Republic of the Congo. Thaddée Badibanga, Catherine Ragasa, and John Ulimwengu, 2013.

1257. The impact of Oportunidades on human capital and income distribution: A top-down/bottom-up approach. Dario Debowicz and Jennifer Golan, 2013.

1256. Filling the learning gap in program implementation using participatory monitoring and evaluation: Lessons from farmer field schools in Zanzibar. Elias Zerfu and Sindu W. Kebede, 2013.

1255. Agricultural mechanization in Ghana: Is specialization in agricultural mechanization a viable business model?: Nazaire Houssou, Xinshen Diao, Frances Cossar, Shashidhara Kolavalli, Kipo Jimah, and Patrick Aboagye, 2013.

1254. A partial equilibrium model of the Malawi maize commodity market. Mariam A. T. J. Mapila, Johann F. Kirsten, Ferdinand Meyer, and Henry Kankwamba, 2013.

1253. Exchange rate policy and devaluation in Malawi. Karl Pauw, Paul Dorosh, and John Mazunda, 2013.

1252. A regional computable general equilibrium model for Honduras: Modeling exogenous shocks and policy alternatives. Samuel Morley and Valeria Piñeiro, 2013.

1251. Agricultural trade: What matters in the Doha Round? David Laborde and Will Martin, 2013.

1250. Opportunities and challenges for community involvement in public service provision in rural Guatemala. Johanna Speer and William F. Vásquez, 2013.

1249. Rising wages in Bangladesh. Xiaobo Zhang, Shahidur Rashid, Kaikaus Ahmad, Valerie Mueller, Hak Lim Lee, Solomon Lemma, Saika Belal, and Akhter Ahmed, 2013.

1248. How are farmers adapting to climate change in Vietnam?: Endogeneity and sample selection in a rice yield model. Bingxin Yu, Tingju Zhu, Clemens Breisinger, and Nguyen Manh Hai, 2013.

1247. Evaluating the local economywide impacts of irrigation projects: Feed the Future in Tanzania. Mateusz Filipski, Dale Manning, J. Edward Taylor, Xinshen Diao, and Angga Pradesha, 2013.

1246. Factor endowments, wage growth, and changing food self-sufficiency: Evidence from country-level panel data . Keijiro Otsuka, Yanyan Liu, and Futoshi Yamauchi, 2013.

1245. Impact of food price changes on household welfare in Ghana. Nicholas Minot and Reno Dewina, 2013.

1244. Parametric decomposition of the Malmquist Index in an output-oriented distance function: Productivity in Chinese agriculture. Bingxin Yu, Xiyuan Liao, and Hongfang Shen, 2013.

1243. Extreme weather and civil war in Somalia: Does drought fuel conflict through livestock price shocks? Jean-Francois Maystadt, Olivier Ecker, and Athur Mabiso, 2013.

1242. Evidence on key policies for African agricultural growth. Xinshen Diao, Adam Kennedy, Ousmane Badiane, Frances Cossar,Paul Dorosh, Olivier Ecker, Hosaena Ghebru Hagos, Derek Headey, Athur Mabiso, Tsitsi Makombe, Mehrab Malek, and Emily Schmid, 2013. 


\section{INTERNATIONAL FOOD POLICY RESEARCH INSTITUTE}

www.ifpri.org

IFPRI HEADQUARTERS

$2033 \mathrm{~K}$ Street, NW

Washington, DC 20006-1002 USA

Tel.: +1-202-862-5600

Fax: +1-202-467-4439

Email: ifpri@cgiar.org

IFPRI ADDIS ABABA

P. O. Box 5689

Addis Ababa, Ethiopia

Tel.: + 251 (0) 11-617-2500

Fax: + 251 (0) 11-646-2927

Email: ifpri-addisababa@cgiar.org 